(1)Especialista en Anatomía Patológica y Patología Clínica. Patología Pulmonar. Doctora en Ciencias Biomédicas con énfasis en Genómica de Tumores Sólidos. Departamento de Patología y Medicina de Laboratorio. Línea de Investigación Biomédica en Tórax. Fundación Valle del Lili. Profesora Clínica Asistente. Facultad de Ciencias de la Salud. Universidad Icesi. Cali, Colombia.

Correspondencia: Luz Fernanda Sua, correos electrónicos: lufer24@hotmail.com, 1fsua@fcvl.org

Recibido: 20/03/16. Aceptado: 30/03/16.

\section{Recomendaciones para la remisión de muestras de tejidos desde Neumología y Cirugía de tórax al Laboratorio de Patología}

\section{Recommendations for the referral of tissue samples from Pulmonology and Chest Surgery to the Pathology Laboratory}

Luz Fernanda Sua, MD., PhD. ${ }^{(1)}$

\section{Introducción}

Según el Código Sanitario Nacional de Colombia, artículo 516 literal $\mathrm{H}$, todos los especímenes quirúrgicos obtenidos a través de procedimientos con fines terapéuticos, estéticos o de diagnóstico deben ser sometidos a examen anatomopatológico. El médico (neumólogo, neumólogo intervencionista y cirujano de tórax) debe remitir al laboratorio de patología, para su estudio, todos los especímenes quirúrgicos obtenidos, así éstos parezcan "normales o libres de malignidad" pues es el médico patólogo quien debe establecer el diagnóstico anatomopatológico definitivo.

La fase preanalítica en patología está definida como cualquier proceso que tenga impacto en las nes) desde el instante en que salen del cuerpo del paciente hasta que llegan al corte en el micrótomo (figura 1) y se realiza su montaje en la lámina histológica. muestras biológicas (bioespecíme-

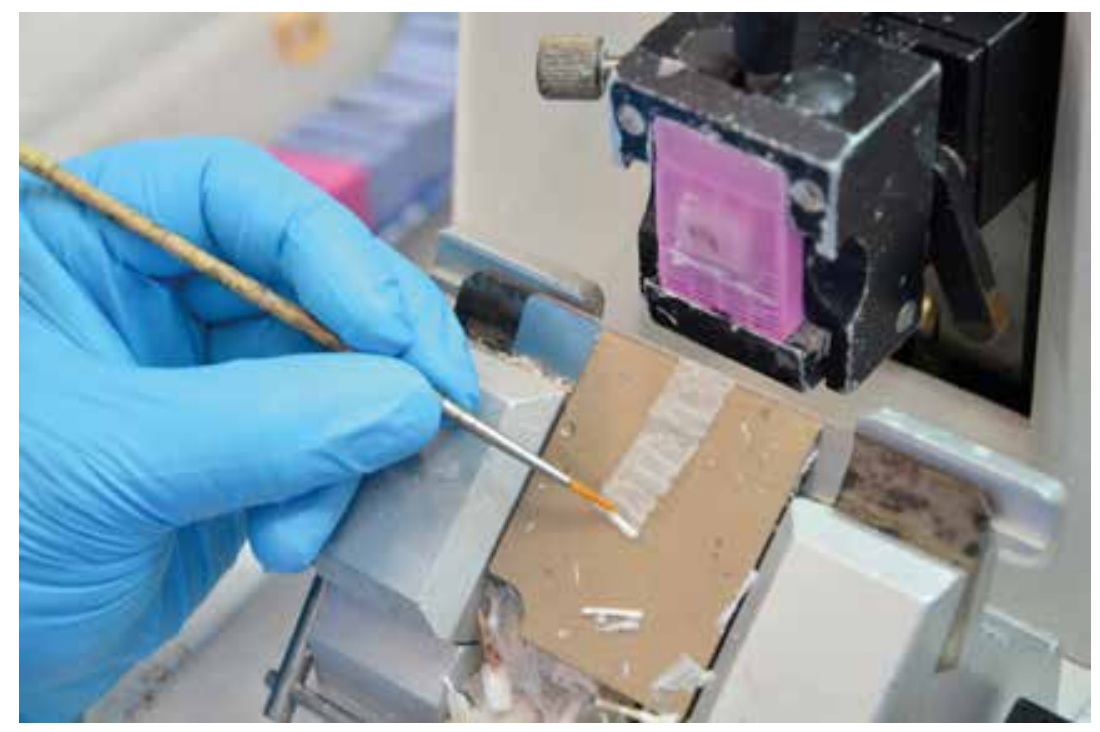

Figura 1. En el micrótomo se observa corte del bloque de tejido incluido en parafina. 
Estas recomendaciones de calidad pretenden estandarizar el proceso y asegurar la calidad de los bioespecímenes para la correcta interpretación de expresiones proteicas con la técnica de imunohistoquímica (IHQ), la correcta hibridación in situ fluorescente (FISH), hibridación in situ cromo génica y con plata dual (DISH), hibridación in situ cromogénica (CISH), extracción de ADN o ARN amplificable para estudios genómicos con la técnica de reacción en cadena de la polimerasa (PCR), genómica con secuenciación y microarreglos o con las nuevas técnicas ómicas introducidas en el estudio de la patología tumoral y no tumoral.

\section{Guia básica de calidad para la remisión de muestras de tejido al laboratorio de patología}

\section{a. ¿Qué información debe tener una orden clínica} o solicitud de examen de patología completa?

- Nombres y apellidos completos del paciente

- Número de documento de identidad

- Fecha de nacimiento y sexo del paciente

- Hora y fecha de la toma de la muestra

- Diagnóstico clínico e indicación del procedimiento

- Tipo de espécimen (ver punto 2)

- Tiempo entre la toma del espécimen e introducción en el fijador

- $\quad$ Tipo de fijador

- Nombre y contacto del médico tratante

- Entidad aseguradora

b. ¿Cuáles son los tipos de especímenes?

- Biopsias tisulares con aguja gruesa

- Biopsias por aspiración con aguja fina

- Biopsias incisionales
- Biopsias escisionales

- Resección completa

c. ¿Cómo se debe rotular la muestra?

- Nombres y apellidos completos del paciente

- Número de documento de identidad

- Fecha de nacimiento del paciente

- Lugar anatómico y tipo de muestra

- Hora y fecha de la toma de la muestra

- Tipo de fijador y de espécimen

\section{d. ¿Cuál es el fijador que debe utilizarse?}

- Formalina al 10\% con sales amortiguantes. Fórmula de preparación:

- Formol 37\%: $100 \mathrm{~mL}$

- Fosfato sódico monobásico: $4 \mathrm{~g}$

- Fosfato sódico dibásico: 6,5 g

- Agua destilada: $900 \mathrm{~mL}$

- Volumen total: $1000 \mathrm{~mL}$

e. ¿Cuál es el uso adecuado del agente fijador?

- Proporción del fijador: a tejido de 20:1, sumergir en formalina al $10 \%$ con sales amortiguantes

- Introducir el tejido en el recipiente inmediatamente se obtenga la muestra

- Realizar cambio del fijador cada 24 horas en piezas de resección

\section{f. ¿Cómo se deben transportar las muestras?}

- El recipiente debe ser adecuado al tamaño del espécimen, hermético e irrompible y estar marcado como agente químico

- La muestra debe venir siempre sumergida en formalina durante su transporte 
- Facilitar al transportador una ficha de seguridad de agente químico (MSDS) para usar en caso de derrame

\section{g. ¿EI tejido puede ser utilizado para diagnóstico histopatológico y además para estudios com- plementarios de patología molecular?}

- El tejido que se procesa de esta manera es óptimo para estudios adicionales de:

- Inmunohistoquímica (IHQ)

- Hibridación in situ por fluorescencia (FISH)

- Hibridación in situ cromogénica (CISH)

- Hibridación in situ cromogénica y con plata o dual (DISH)

- Extracción de ADN y ARN

- Amplificación por reacción en cadena de la polimerasa (PCR)

- Genómica por secuenciación/microarreglos

\section{Conclusión}

La calidad de un estudio histopatológico confiable, depende de la fijación correcta de los tejidos y esta responsabilidad corresponde al médico que remite el material al laboratorio de patología.El tejido debe introducirse inmediatamente al recipiente con el fijador. Las piezas grandes no deben superar los 60 minutos expuestas al medio ambiente.

La fijación para biopsias debe ser mínimo de 6 horas y máximo 72 horas (promedio 18 h) y la fijación para piezas de resección debe ser mínimo de 6 horas y máximo 72 horas (promedio 36 h) para iniciar su proceso histológico $(1,2)$.

Los tiempos demasiado cortos o largos de fijación alteran las pruebas de patología molecular; estas muestras sufren deterioros severos y no pueden ser utilizadas para el diagnóstico patológico.

\section{Conflictos de interés}

La autora declara no tener conflictos de interés.

\section{Bibliografía}

1. Bussolati, G, Annaratone L, Medico E, D‘Armento G, Sapino A. Formalin fixation at low temperature better preserves nucleic acid integrity. 2011, PLOS One NE. DOI: 10.1371/journal.pone.0021043.

2. Wolff AC, Hammond ME, Hicks DG, Dowsett M, McShane LM, Allison KH, et al. Recommendations for human epidermal growth factor receptor 2 testing in breast cancer: American Society of Clinical Oncology/College of American Pathologists Clinical Practice Guideline Update. Arch Pathol Lab Med. 2014;138:241-56; DOI: 10.5858/arpa. 2013 - 0953 - SA. 